\title{
Institutional Chaplaincy
}

An institutional chaplain is simply a pastor who carries on his ministry in a mental hospital, a general hospital, or a prison. The difference between the work of the parish pastor and the chaplain is one of setting in which the work is done rather than the work itself. My feeling is that the setting is a rather indifferent matter.

Each day as a pastor, the ministry of the gospel makes more sense to me. This is because I am deeply convinced that all people are struggling with a god-problem. We are trying to decide who we want on the throne of our lives-God or our own egos. The choice for ego enthronement is made very early-as early as toilet-training when we insisted on using a warm diaper rather than that cold potty. Though we lost that battle, we continued the War of the Wills, as our parents can testify. The battle between "my terms" and "another's terms" goes on through the developmental years. If "my terms" prevail, I am my own god, my own ultimate source of power, the captain of my soul. Such a peison is mispositioned in the world and this eventually leads to no end of mal-function-neurosis, alcoholism, marital conflict, depression, physical illness, etc.

The pastor's task is to set the stage for the abandonment of one's egocentricity and the subjection of the soul to Higher Power. Most people are unaware of their egocentric style of life. It is one of the pastor's tasks to help the lost, suffering person understand his plight. This must be done in love-without judgment or coercion of any kind. I am amazed, not at how few respond with interest but how many see God's light shining in their darkness for the first time in their lives. Some of these people, however, will fall away when it comes to the dying process (the message of the cross) to which the pastor now invites them. The stage is set for this by the invitation to auricular confession, by a full discussion of appropriate apologies and restitutions, by the suggestion that one develop a religious life on God's terms. It is true that only a remnant of my parishioners go all the way to an authentic enthronement of Christ as King of their lives. What amazes me, however, is that any' come to the New Life because, as a mental hospital chaplain, I can give a clinical testimony that we are "dead in our trespasses and sins." How then do the dead come back to life? By the sovereign, gracious power of the Holy Spirit. As a pastor, I am God's stage-hand. I move the furniture around but the Director runs the show and directs the actors. For many years I tried to be the director using my skill, my training, my brains, but most of all, my oceanic egoism! It never really worked. But, by God's grace, I died. And now I am alive, but not I for it is Christ who lives in me. Now life has meaning; my work as a pastor is deeply satisfying; the Kingdom of God is abuilding marvelously; the Holy Spirit is at work even more than at Pentecost; and nothing can really go wrong in my Father's world because the ultimate victory has already been won by the King. 